\title{
KORELASI MULTIVARIABEL ENSO, MONSUN DAN DIPOLE MODE TERHADAP VARIABILITAS CURAH HUJAN DI MALUKU
}

\author{
Alexander Y. Elake ${ }^{1,2}$, Merlin Talahatu ${ }^{1}$, Pieldrie Nanlohy ${ }^{1,2}$ \\ ${ }^{1}$ Jurusan Fisika Fakultas Matematika dan Ilmu Pengetahuan Alam, Universitas Pattimura \\ Jalan Ir. M. Putuhena, Kampus Unpatti, Poka-Ambon, Indonesia \\ ${ }^{2}$ Pusat Pengolahan Infrakstruktur Data Spasial (PPIDS) Universitas Pattimura \\ Jalan Ir. M. Putuhena, Kampus Unpatti, Poka-Ambon, Indonesia \\ e-mail: ${ }^{12}$ yosepelake@yahoo.co.id; ${ }^{1,2}$ pieldrienanlohy@gmail.com
}

\begin{abstract}
Abstrak
Analisis korelasi multivariabel antara curah hujan di Maluku (Ambon, Tual, dan Saumlaki) dengan anomali suhu the El Niño Southern Oscillation (ENSO) di daerah Niño 3.4 Samudera Pasifik, angin Monsun di wilayah Maluku serta anomali suhu Dipole Mode Event (DME) di Samudera Hindia telah dilakukan dengan analisa korelasi parsial dan berganda. Analisis tersebut dilakukan untuk data selama 10 tahun kalender yaitu dari Januari 2005 - Desember 2014 yang meliputi dua periode kejadian El Niño (tahun 2006/07 dan 2009/10), dua tahun fasa ENSO Normal (2005 dan 2013), dan tiga periode La Niña (2007/08, 2010/11, dan 2011/12). Pengaruh interaksi ENSO, Monsun dan Dipole Mode terhadap curah hujan Maluku ditunjukkan oleh nilai koefisien korelasi berganda (rb1) yang berkisar antara 0,748 - 0,999 dan nilai koefisien penentu berganda (rpb1) dengan kisaran 55,9-99,8\% pada fasa El Niño. Sedangkan untuk fasa ENSO Normal nilainya berturut-turut $\mathrm{rb2}=0,807-0,905$ dan $\mathrm{rpb} 2=64,6-81,9 \%$, dan untuk fasa fasa La Niña adalah $\mathrm{rb3}_{\mathrm{b}}=0,674-0,964$ dan $\mathrm{rpb3}=45,4-92,9 \%$. Pengaruh ENSO yang dominan terhadap curah hujan Ambon terlihat pada fasa El Niño dan fasa La Niña, sedangkan Monsun lebih dominan pada ENSO Normal. Untuk Tual, pengaruh ENSO, Monsun, dan Dipole Mode sama-sama terlihat pada fasa El Niño dan fasa La Niña, sedangkan Monsun lebih dominan dari Dipole Mode pada ENSO Normal. Sementara pengaruh Dipole Mode sangat dominan terhadap curah hujan Saumlaki.
\end{abstract}

Kata Kunci: Korelasi multivariabel, curah hujan, ENSO, Monsun, Dipole Mode

\section{MULTIVARIABEL CORELATION ENSO, MONSUN AND DIPOLE MODE OF RAINFALL VARIABILITY IN MOLLUCAS}

\begin{abstract}
Multivariable correlation analysis between rainfall in the Maluku (Ambon, Tual, and Saumlaki) with temperature anomaly of The El Niño Southern Oscillation (ENSO) in the Niño 3.4 area in the Pacific Oceans, wind of Monsoon in the Maluku area and temperature anomaly of Dipole Mode Event (DME) in the Hindia Oceans has been done with partial and double correlation analysis. The analysis done for data during 10 calender years (January 2005 - December 2014) that is two phase periods of El Niño (the year 2006/07 and 2009/10), two years normal phase of ENSO (2005 and 2013), and three years phase period of La Niña (2007/08, 2010/11, and 2011/12). Influence of ENSO, Monsoon and Dipole Mode interaction to rainfall shown by double correlation coefficient value ( $\mathrm{rb} 1$ ) is ranging from 0,748 - 0,999 and double determinant coefficient value (rpb1) with the range of 55,9 - 99,8\% at El Niño phase. While for Normal phase of ENSO are rb2 $=0,807-0,905$ and $\mathrm{rpb} 2=64,6-81,9 \%$, and phase of La Niña are rb3 $=0,674-0,964$ and rpb3 $=45,4-92,9 \%$. Influence of ENSO which is dominant to Ambon rainfall seen of El Niño and La Niña phases, while Monsun is dominant of Normal phase of ENSO. In Tual, influence of ENSO, Monsun, and Dipole Mode are simultan seen of El Niño and La Niña phases, while Monsun is dominant better than Dipole Mode of Normal phase of ENSO. Influence of Dipole Mode is dominant to Saumlaki rainfall.
\end{abstract}

Keywords : Multivariable Correlation, Rainfall, ENSO, Monsoon, Dipole Mode 


\section{Pendahuluan}

Maluku sebagai bagian dari Benua Maritim Indonesia (BMI) secara geografis posisinya terletak antara Benua Asia dan Australia serta antara Samudera Hindia dan Pasifik. Kondisi ini mempengaruhi dinamika dan karakteristik lingkungan atmosfer (curah hujan, suhu, angin, dan kelembaban) dan laut (suhu salinitas, arus laut dan kesuburan perairan laut) [1]. Curah hujan di wilayah Maluku dominan dipengaruhi oleh sistem angin monsun. Sistem angin ini berhubungan dengan adanya sistim tekanan udara tinggi dan tekanan udara rendah di benua Asia dan Australia. Intensitas curah hujan di Maluku juga sangat di pengaruhi oleh kondisi suhu permukaan laut di perairan Samudera Hindia dan Samudera Pasifik. Fenomena El Nino atau La Nina di Samudera Pasifik dan fenomena Indian Ocean Dipole (IOD) yang terjadi di bagian tropis Samudera Hindia dan dapat menyebabkan terjadinya anomali suhu permukan laut di kedua perairan tersebut.

Kondisi ini ternyata mempengaruhi jumlah curah hujan di sekitar perairan tersebut termasuk wilayah Maluku. Fenomena El Nino dan Indian Ocean Dipole (+) adalah penurunan curah hujan, sehingga masa tanam lebih pendek. Sebaliknya La Nina dan Indian Ocean Dipole (-) menyebabkan peningkatan jumlah curah hujan dengan demikian masa tanam lebih lama [2]. Pola variabilitas curah hujan di Maluku, hubungannya dengan fenomena ENSO (El Nino - southern oscillation) di Samudera Pasifik, Monsun di peraian Maluku dan Dipole Mode Event (DME) di Samudera Hindia, dan pengaruh ketiga variabel tersebut (ENSO, Monsun dan Dipole Mode) terhadap variabilitas curah hujan di Maluku akan dijelaskan dalam penelitian ini.

\section{Metode Penelitian}

Penelitian ini berlokasi di wilayah Provinsi Maluku yang meliputi 3 lokasi yaitu : (1) Ambon mewakili wilayah Maluku bagian Utara, (2) Tual mewakili wilayah Maluku bagian Tengah dan (3) Saumlaki mewakili wilayah Maluku bagian Selatan (Gambar 1).

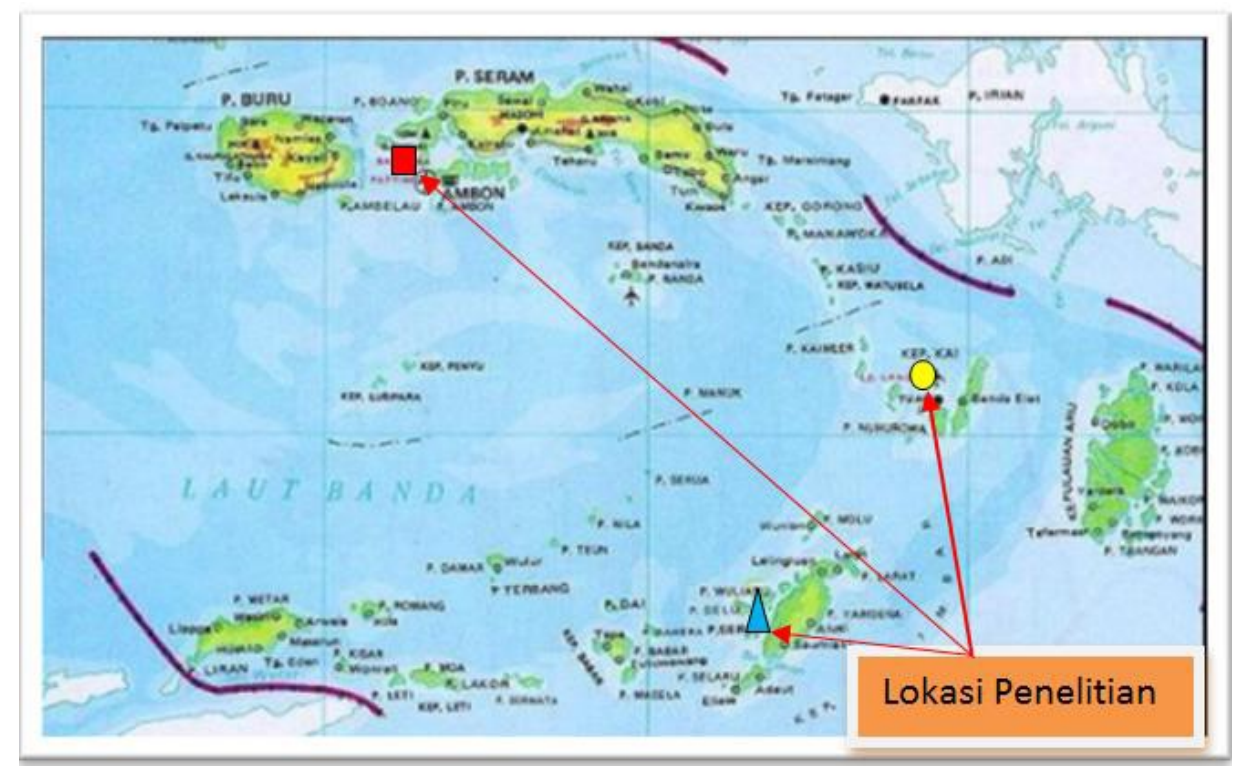

Gambar 1. Lokasi Penelitian

Data yang digunakan dalam penelitian ini meliputi: (a) data curah hujan di Maluku untuk tiga wilayah yaitu Ambon, Tual dan Saumlaki diperoleh dari BMKG Bandara Pattimura dan stasiun Geofisika Karang Panjang Ambon untuk periode data mulai dari Januari 2005 sampai Desember 2014 selama 10 tahun; (b) data Indeks ENSO yang diperoleh dari anomali SPL di niño $3.4\left(120^{\circ} \mathrm{BB}-170^{\circ} \mathrm{BB}\right.$ dan $\left.5^{\circ} \mathrm{LU}-5^{\circ} \mathrm{LS}\right)$ yang diperoleh dari http://www.cdc.noaa.gov; (c) data Indeks Monsun berupa komponen kecepatan angin meridional dan zonal di wilayah Maluku yang merupakan data angin rata-rata bulanan yang diperoleh dari http://www.ncep.gov; dan (d) data Indeks Dipole Mode (IDM) yang ditentukan dari perbedaan anomali SPL Samudera Hindia ekuator bagian barat $\left(50^{\circ} \mathrm{BT}-70^{\circ} \mathrm{BT}\right.$ dan $\left.10^{\circ} \mathrm{LS}-10^{\circ} \mathrm{LU}\right)$ dengan anomali SPL 
Samudera Hindia di lepas pantai Sumatera $\left(90^{\circ} \mathrm{BT}-110^{\circ} \mathrm{BT}\right.$ dan $10^{\circ} \mathrm{LS}$ - ekuator), yang diperoleh dari http://www.jamstec.go.jp.

Hubungan antara curah hujan dengan ENSO, Monsun dan Dipole Mode dapat diketahui dengan melakukan analisis hubungan. Penerapan analisis hubungan ini berfungsi untuk mengetahui derajat atau kekuatan hubungan, bentuk atau arah hubungan di antara variabel-variabel, dan besarnya pengaruh variabel yang satu (variabel bebas, variabel independen) terhadap variabel lainnya (variabel terikat, variabel dependen). Teknik statistik yang digunakan dalam analisis hubungan adalah analisis korelasi (koefisien korelasi dan koefisien penentu). Koefisien korelasi adalah bilangan yang digunakan untuk mengukur derajat hubungan, meliputi kekuatan hubungan dan bentuk/arah hubungan. Untuk kekuatan hubungan, nilai koefisien korelasi berada di antara -1 dan +1 . Untuk bentuk/arah hubungan, nilai koefisien korelasi dinyatakan dalam positif $(+)$ dan negatif $(-)$, atau $(-1 \leq \mathrm{KK} \leq+1)$. Koefisien penentu (KP) adalah angka atau indeks yang digunakan untuk mengetahui besarnya sumbangan sebuah variabel atau lebih (variabel bebas, $\mathrm{X}$ ) terhadap variasi (naik/turunnya) variabel yang lain (variabel terikat, Y), dengan nilai KP berada antara 0 sampai $1(0 \leq \mathrm{KP} \leq 1)$. Analisis Korelasi Parsial dan Analisis Korelasi Berganda akan digunakan untuk menganalisa hubungan antara curah hujan di wilayah Maluku (Ambon, Tual, dan Saumlaki) dengan ENSO, Monsun, dan Dipole Mode. Koefisien korelasi parsial ( $\mathrm{r} p$ ) adalah koefisien korelasi untuk mengukur keeratan hubungan dari dua variabel, sedangkan variabel lainnya dianggap konstan (tidak memberikan pengaruh) pada hubungan yang melibatkan lebih dari dua variabel. Sementara itu koefisien penentu parsial (rpp) adalah koefisien penentu untuk mengukur besarnya pengaruh sebuah variabel (variabel bebas) terhadap sebuah variabel lainnya (variabel terikat) jika variabel-variabel lainnya dianggap konstan pada hubungan yang melibatkan lebih dari dua variabel.

Nilai Koefisien Korelasi Parsial dan Koefisien Penentu Parsial untuk tiga variabel dirumuskan sebagai berikut [3]:

a) Untuk hubungan antara $\mathrm{Y}$ dan $\mathrm{X}_{1}$ apabila $\mathrm{X}_{2}$ konstan

$$
r_{Y 1.2}=\frac{r_{Y 1}-r_{Y 2} \cdot r_{12}}{\left\{\left(1-r_{Y 2}^{2}\right)\left(1-r_{12}^{2}\right)\right\}^{1 / 2}}
$$

dan

$$
r p_{p}=r_{Y 1.2}^{2} \times 100 \%
$$

b) Untuk hubungan antara $\mathrm{Y}$ dan $\mathrm{X}_{2}$ apabila $\mathrm{X}_{1}$ konstan

$$
r_{Y 2.1}=\frac{r_{Y 2}-r_{Y 1} \cdot r_{12}}{\left\{\left(1-r_{Y 1}^{2}\right)\left(1-r_{12}^{2}\right)\right\}^{1 / 2}}
$$

dan

$$
r p_{p}=r_{Y 2.1}^{2} \times 100 \%
$$

c) Untuk hubungan antara $\mathrm{X}_{1}$ dan $\mathrm{X}_{2}$ apabila $\mathrm{Y}$ konstan

$$
r_{12 . Y}=\frac{r_{12}-r_{Y 1} \cdot r_{Y 2}}{\left\{\left(1-r_{Y 1}^{2}\right)\left(1-r_{Y 2}^{2}\right)\right\}^{1 / 2}}
$$

dan

$$
r p_{p}=r_{12 . Y}^{2} \times 100 \%
$$

dimana:

$r_{Y 1.2}=$ koefisien korelasi parsial antara $\mathrm{Y}$ dan $\mathrm{X}_{1}$ apabila $\mathrm{X}_{2}$ konstan

$r_{Y 2.1}=$ koefisien korelasi parsial antara $\mathrm{Y}$ dan $\mathrm{X}_{2}$ apabila $\mathrm{X}_{1}$ konstan

$r_{12 . Y}=$ koefisien korelasi parsial antara $\mathrm{X}_{1}$ dan $\mathrm{X}_{2}$ apabila $\mathrm{Y}$ konstan

$r_{Y 1}=$ koefisien korelasi silang antara $\mathrm{Y}$ dan $\mathrm{X}_{1}$

$r_{Y 2}=$ koefisien korelasi silang antara $\mathrm{Y}$ dan $\mathrm{X}_{2}$

$r_{12}=$ koefisien korelasi silang antara $\mathrm{X}_{1}$ dan $\mathrm{X}_{2}$

Koefisien korelasi berganda $\left(\mathrm{r}_{\mathrm{b}}\right)$ adalah koefisien korelasi untuk mengukur keeratan hubungan antara tiga variabel atau lebih. Nilai koefisien korelasi berganda untuk tiga variabel dirumuskan sebagai berikut :

$$
R_{Y 1.2}=\left(\frac{r_{Y 1}^{2}+r_{Y 2}^{2}-2 r_{Y 1} r_{Y 2} r_{12}}{1-r_{12}^{2}}\right)^{1 / 2}
$$


dimana:

$$
\begin{aligned}
& R_{Y 1.2}=\text { koefisien korelasi berganda tiga variabel } \\
& r_{Y 1}=\text { koefisien korelasi variabel Y dan } \mathrm{X}_{1} \\
& r_{Y 2}=\text { koefisien korelasi variabel Y dan } \mathrm{X}_{2} \\
& r_{12} \quad=\text { koefisien korelasi variabel } \mathrm{X}_{1} \text { dan } \mathrm{X}_{2}
\end{aligned}
$$

Koefisien penentu berganda $\left(\mathrm{rp}_{\mathrm{b}}\right)$ adalah koefisien korelasi untuk menentukan besarnya pengaruh variasi (naik/turunnya) nilai variabel bebas (variabel $\mathrm{X}$ ) terhadap variasi (naik/turunnya) nilai variabel terikat (variabel Y) pada hubungan lebih dari dua variabel. Nilai KPB untuk tiga variabel dirumuskan sebagai berikut (Hasan, 2004):

$$
r_{b}=R_{Y 1.2}^{2} \times 100 \%
$$

dimana :

$$
R_{Y 1.2}^{2}=\text { koefisien korelasi berganda untuk tiga variabel. }
$$

Dalam penelitian ini, perhitungan nilai koefisien korelasi berganda dan koefisien korelasi parsial (untuk korelasi lebih dari dua variabel) dilakukan dengan menggunakan software Statistica versi 10.

\section{Hasil}

\subsection{Variasi Bulanan Curah Hujan di wilayah Maluku}

Curah hujan di wilayah Maluku untuk tiga wilayah penelitian (Ambon, Tual dan Saumlaki) sangat beragam. Dengan menggunakan data dari BMKG selama 10 tahun terhitung sejak Januari 2005 Desember 2014 menunjukan bahwa pada setiap bulan untuk wilayah Maluku mengalami kondisi yang berbeda-beda. Perbedaan sebaran curah hujan tersebut disebabkan karena adanya gerak semu matahari, sirkulasi angin global dan topografi wilayah yang diamati.

Variasi bulanan curah hujan di wilayah Maluku dari data BMKG periode data Januari 2005Desember 2014 memperlihatkan pola hujan yang berbeda. Ambon mempunyai pola hujan lokal, sedangkan Tual dan Saumlaki memiliki pola hujan Monsun. Pola hujan ini sesuai dengan hasil kajian peneliti-peneliti sebelumnya [4].

Wilayah Maluku (Ambon, Tual, dan Saumlaki) mempunyai pola curah hujan yang berbeda-beda satu dengan yang lainnya (Gambar 2). Pola curah hujan Ambon adalah pola curah hujan Lokal, dimana curah hujan terendah pada musim Barat (156 mm/bln) dan tertinggi pada musim Timur (635 mm/bln), sedangkan pola curah hujan untuk Tual dan Saumlaki adalah Monsun. Curah hujan terendah untuk Tual terjadi di musim Peralihan II (18 mm/bln) dan tertinggi di Peralihan I (91 mm/bln). Sementara Saumlaki mengalami puncak terendah di musim musim Paralihan II (108 mm/bln) dan tertinggi di musim Barat (334 mm/bln).

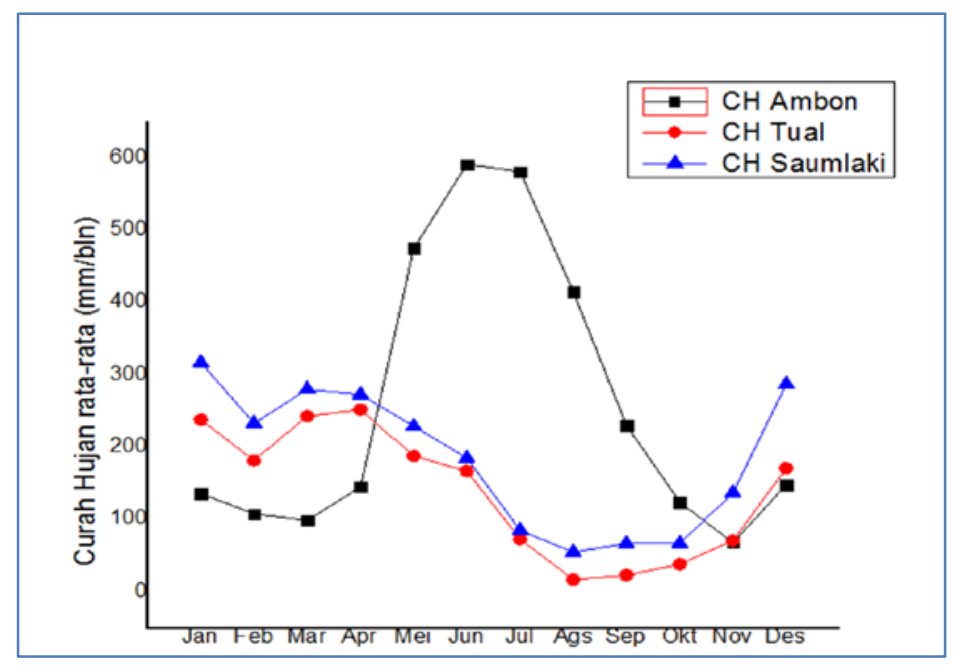

Gambar 2. Pola Curah Hujan wilayah Maluku (Ambon, Tual, dan Saumlaki) untuk data curah hujan dari BMKG periode Januari 2005 - Desember 2014. 


\subsection{Monsun di Wilayah Maluku}

Monsun di Wilayah Maluku ditunjukkan oleh kecepatan rata-rata angin permukaan yang bertiup di wilayah Maluku dari tahun 2005-2014. Data amgin permukaan adalah data 6 Jam-an yang diperoleh dari http://www.ncep.gov yang kemudian di olah dengan program Grid Analysis and Display System (GrADS) untuk mendapatkan dan menampilkan kecepatan angin rata-rata di daerah kajian (Gambar 3).

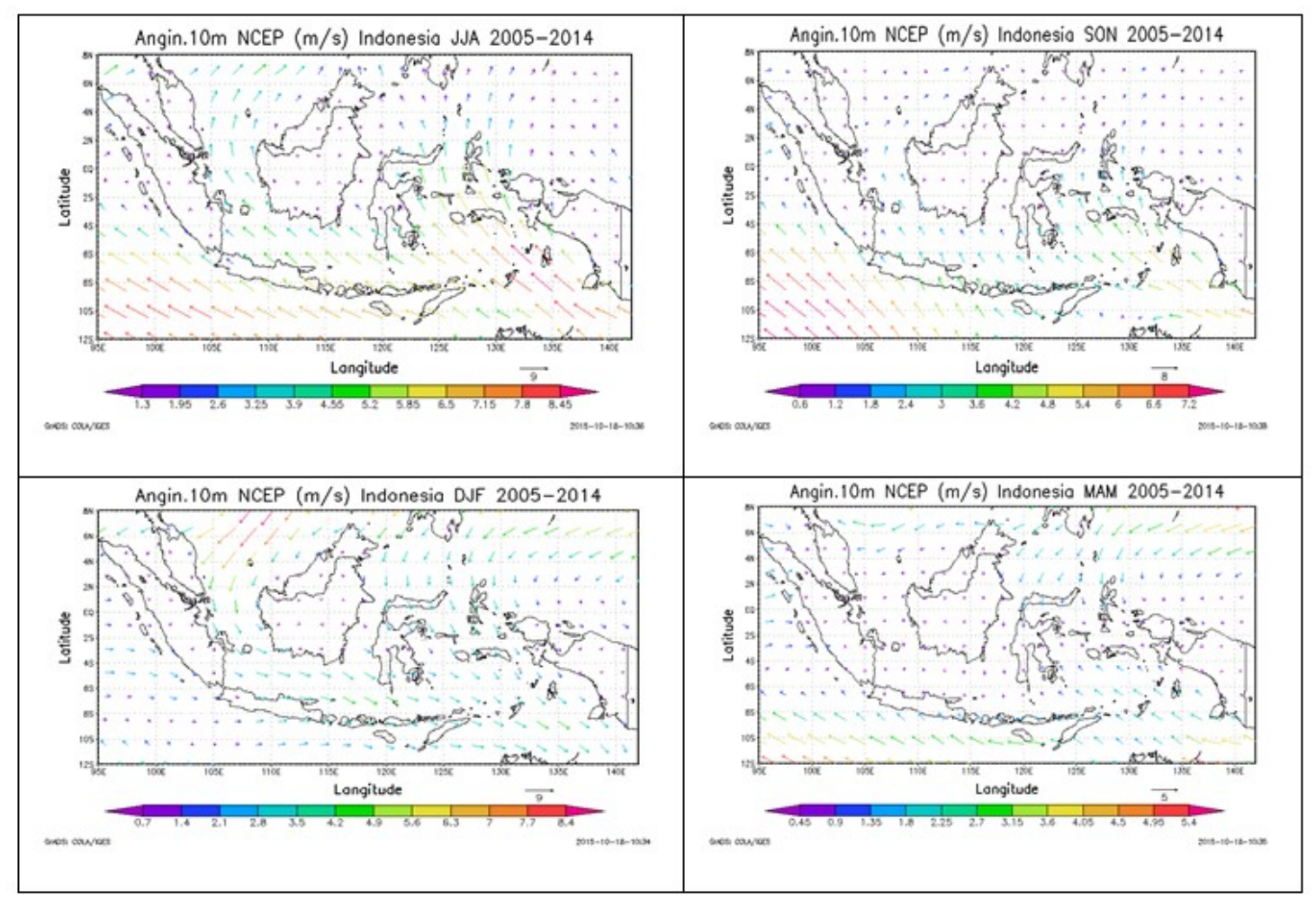

Gambar 3. Angin Permukaan Indonesia (m/s) untuk bulan (a) JJA, (b) SON, (c) DJF, (d) MAM tahun 2005-2014.

Pada musim Timur yaitu bulan Juni - Juli - Agustus (JJA), angin bertiup dari arah Tenggara dan ketika melewati ekuator dibelokan ke arah utara. Kecepatan angin pada musim Timur (JJA) berkisar antara 5$9 \mathrm{~m} / \mathrm{s}$. Pada musim Peralihan I yaitu bulan September - Oktober - November (SON), angin bertiup dari arah Tenggara dan ketika melewati ekuator dibelokan ke arah utara. Hal ini sama saja dengan angin waktu musim Timur (JJA) namun pada musim Peralihan I (SON), kecepatan angin mulai lambat, dan berkisar antara 2-6 m/s, sedangkan pada musim Barat yaitu pada bulan Desember - Januari - Februari (DJF), arah anginnya berbalik arah dari utara ke tenggara, dengan kecepatan angin hampir seragam, yaitu berkisar antara 2 - $3 \mathrm{~m} / \mathrm{s}$. Sementara pada musim Peralihan I yaitu pada bulan Maret - April - Mei (MAM), arah anginnya dari tenggara menuju utara dengan kecepatan berkisar antara $1,5-2 \mathrm{~m} / \mathrm{s}$.

\subsection{Kondisi ENSO berdasarkan Indeks Niño 3.4}

Kondisi anomali suhu permukaan laut (SPL) di wilayah Niño 3.4 dengan anomali suhu positif diatas $0.4{ }^{\mathrm{O}} \mathrm{C}$ dan bertahan selama 6 bulan diindikasikan terjadinya El Niño dan jika anomali suhu negatif dibawah $0.4{ }^{\circ} \mathrm{C}$ dan bertahan selama 6 bulan diindikasikan terjadinya La Niña ${ }^{[5]}$. Selama kurun waktu tahun 2005 - 2014 telah terjadi 2 kali fasa El Niño, 2 kali fasa Normal, dan 3 kali La Niña, seperti terlihat pada Tabel 1. 
Tabel 1. Kejadian El Niño dan La Niña berdasarkan Indeks Niño 3.4

\begin{tabular}{|c|l|l|l|c|} 
No & Kejadian & \multicolumn{1}{|c|}{ Periode } & \multicolumn{1}{|c|}{ Puncak } & Anomali Suhu \\
1 & El Niño 1 & Agustus 2006 - Januari 2007 (6 bulan) & Desember 2006 & 1.19 \\
\hline 2 & El Niño 2 & Juni 2009 - April 2010 (11 bulan) & Desember 2009 & 1.72 \\
\hline 3 & Normal 1 & Februari 2005 - November 2005 (9 bulan) & Juni 2005 & 0.4 \\
\hline 4 & Normal 2 & Februari 2013 - Desember 2013 (11 bulan) & Februari 2013 & -0.4 \\
\hline 5 & La Niña 1 & Juli 2007 - Juni 2008 (12 bulan) & Februari 2008 & -1.89 \\
\hline 6 & La Niña 2 & Juni 2010 - Mei 2011 (12 bulan) & Oktober 2010 & -1.68 \\
\hline 7 & La Niña 3 & Agustus 2011 - Maret 2012 (8 bulan) & Januari 2012 & -1.08 \\
\hline
\end{tabular}

\subsection{Kondisi Dipole Mode berdasarkan Indeks Dipole Mode}

Dipole Mode positif terjadi jika nilai Indeks Dipole Mode ( IDM) positif lebih besar dari 1 dan Dipole Mode negatif terjadi jika nilai DMI negatif lebih kecil dari 1 setidaknya selama 3 bulan berturut-turut [6]. Selama tahun 2005 - 2014 telah terjadi 1 kali fasa Dipole Mode positif yaitu pada peride September 2006 - November 2006 dengan puncaknya pada bulan Oktober 2006 dengan anomali suhu sebesar $1.5^{\circ} \mathrm{C}$.

\subsection{Korelasi Curah Hujan di wilayah Maluku dengan ENSO, Monsun, dan Dipole Mode}

Analisa korelasi multivariabel curah hujan wilayah Maluku (Ambon, Tual, dan Saumlaki) dengan ENSO, Monsun dan DM dilakukan pada ketiga fasa ENSO, yaitu fasa El Niño pada tahun 2006/07 dan 2009/10, fasa Normal untuk tahun 2005 dan 2013, dan tahun 2007/08, 2010/11, dan 2011/12 yang mewakili fasa La Niña.

\subsubsection{Ambon}

Pada periode El Niño 2006/07 dan 2009/10, hasil analisa korelasi parsial antara curah hujan Ambon dengan ENSO, Monsun dan DM diperoleh hasil bahwa terdapat hubungan yang signifikan hanya antara curah hujan Ambon dengan ENSO pada El Niño 2009/10 saat lag time = -1. Sementara hasil analisa korelasi berganda antara curah hujan Ambon dengan A-SPL di Niño 3.4, kecepatan angin dan indeks dipole mode memperlihatkan bahwa terdapat hubungan yang signifikan antara curah hujan Ambon dengan ENSO, Monsun dan Dipole Mode hanya pada El Niño 2009/10 saat lag time = -1 dengan nilai koefisien korelasi berganda sebesar $r b=0,748$.

Pada periode Normal tahun 2005 dan 2013, diperoleh hasil bahwa Monsun memberikan pengaruh yang signifikan terhadap variabilitas curah hujan Ambon pada periode Normal tahun 2005, sedangkan DM memberikan pengaruh yang signifikan pada periode Normal tahun 2013. Sementara ENSO, Monsun, dan DM secara bersama-sama dan signifikan mempengaruhi variabilitas curah hujan Ambon pada kedua fasa Normal yaitu tahun 2005 dan 2013. Pengaruh ketiga variabel tersebut terhadap variabilitas curah hujan Ambon lebih besar saat fasa Normal tahun 2013 (rpb = 68,1\%) daripada saat fasa Normal tahun 2005 (rpb $=55,9 \%)$.

Pada periode La Niña, pengaruh ENSO terhadap variabilitas curah hujan Ambon dengan mengabaikan pengaruh Monsun dan DM terlihat pada ketiga fasa La Niña (2007/08, 2010/11, dan 2011/12), sedangkan Monsun hanya pada tahun 2010/11, sementara Dipole Mode pada tahun 2011/12. Sementara ENSO, Monsun, dan DM secara bersama-sama dan signifikan mempengaruhi variabilitas curah hujan Ambon pada ketiga fasa La Niña yaitu tahun 2007/08, 2010/11, dan 2011/12. Urutan kekuatan hubungan ketiga variabel tersebut terhadap variabilitas curah hujan Ambon mulai dari terbesar - terkecil adalah: fasa Normal tahun 2011/12 (rb = 0.964), 2010/11 ( $\mathrm{rb}=0.893)$, dan 2007/08 ( $\mathrm{rb}=0.577)$.

\subsubsection{Tual}

Pada periode El Niño 2006/07 dan 2009/10, ENSO dan DM memberikan pengaruh yang signifikan terhadap varibilitas curah hujan Tual hanya pada periode El Niño 2006/07, sedangkan Monsun pada kedua periode El Niño yaitu 2006/07 dan 2009/10. Sementara hasil analisa korelasi berganda antara curah hujan Tual dengan A-SPL di Niño 3.4, kecepatan angin dan indeks dipole mode memperlihatkan 
bahwa terdapat hubungan yang signifikan antara curah hujan Tual dengan ENSO, Monsun dan DM untuk kedua periode El Niño, namun dengan nilai koefisien korelasi berganda yang berbeda, yaitu: $r b=0,748$ (saat lag time = 0) untuk periode El Niño 2006/07, sedangkan rb = 0,954 (saat lag time $=-1$ ) untuk periode El Niño 2009/10.

Pada periode Normal tahun 2005 dan 2013, Monsun memberikan pengaruh yang signifikan terhadap variabilitas curah hujan Tual pada periode Normal tahun 2005 dan 2013, sedangkan DM memberikan pengaruh yang signifikan pada periode Normal tahun 2013. Sementara ENSO, Monsun, dan DM secara bersama-sama dan signifikan mempengaruhi variabilitas curah hujan Tual pada kedua fasa Normal yaitu tahun 2005 dan 2013. Pengaruh ketiga variabel tersebut terhadap variabilitas curah hujan Tual lebih besar saat fasa Normal tahun $2013\left(\mathrm{rp}_{\mathrm{b}}=81,9 \%\right)$ daripada saat fasa Normal tahun $2005\left(\mathrm{rp}_{\mathrm{b}}=77,6\right)$. Pada ketiga fasa La Niña, Pengaruh ENSO terhadap variabilitas curah hujan Tual dengan mengabaikan pengaruh Monsun dan DM terlihat pada fasa La Niña (2007/08), sedangkan pengaruh Dipole Mode terhadap variabilitas curah hujan Tual dengan mengabaikan pengaruh ENSO dan Monsun terlihat pada La Niña 2010/11. Sementara ENSO, Monsun, dan DM secara bersama-sama dan signifikan mempengaruhi variabilitas curah hujan Tual pada fasa La Niña 2007/08 dan 2010/11, dengan masing-masing nilai koefisien korelasi berganda berturut-turut, yaitu: $\mathrm{r}_{\mathrm{b}}=0,857($ lag time $=-1)$ dan $\mathrm{r}_{\mathrm{b}}=0.674(\operatorname{lag}$ time $=0)$.

\subsubsection{Saumlaki}

Pada periode El Niño 2006/07 dan 2009/10, DM memberikan pengaruh yang signifikan terhadap varibilitas curah hujan Saumlaki hanya pada periode El Niño tahun 2006/07, sedangkan Monsun pada periode El Niño tahun 2009/10. Sementara Hasil analisa korelasi berganda antara curah hujan Saumlaki dengan A-SPL di Niño 3.4, kecepatan angin dan indeks dipole mode memperlihatkan bahwa terdapat hubungan yang signifikan antara curah hujan Saumlaki dengan ENSO, Monsun dan DM untuk kedua periode El Niño, namun dengan nilai koefisien korelasi berganda yang berbeda, yaitu: $\mathrm{r}_{\mathrm{b}}=0,999$ (saat lag time $=+1$ ) untuk periode El Niño 2006/07, sedangkan $r_{b}=0,879$ (saat lag time $=-1$ ) untuk periode El Niño 2009/10.

Pada periode Normal tahun 2005 dan 2013, ENSO dan DM, masing-masing memberikan pengaruh yang signifikan terhadap variabilitas curah hujan Tual pada periode Normal tahun 2005. Namun demikian pengaruh DM (rpp3 = 57,9\%) lebih besar jika dibandingkan dengan pengaruh ENSO ( $\mathrm{rpp} 1=57,4 \%$ ). Sementara ENSO, Monsun, dan DM secara bersama-sama dan signifikan mempengaruhi variabilitas curah hujan Saumlaki hanya pada fasa Normal yaitu tahun 2005. Pengaruh ketiga variabel tersebut terhadap variabilitas curah hujan Saumlaki sebesar 79,5\%, selebihnya 20,5\% berasal dari faktor-faktor lain.

Pada ketiga fasa La Niña, Pengaruh DM terhadap variabilitas curah hujan Saumlaki dengan mengabaikan pengaruh ENSO dan Monsun terlihat hanya pada fasa La Niña 2007/08. Sementara ENSO, Monsun, dan DM secara bersama-sama dan signifikan mempengaruhi variabilitas curah hujan Tual hanya pada fasa La Niña 2007/08 dengan nilai koefisien korelasi berganda sebesar rb = 0,801 pada lag time $=-1$.

\section{Pembahasan}

Dari hasil analisa korelasi parsial yang dilakukan memberikan hasil bahwa pada tahun kejadian El Niño yang dikaji, naik turunnya curah hujan di Ambon sangat dipengaruhi oleh fenomena ENSO dibandingkan dengan Monsun maupun DM. Pada tahun kejadian La Niña, sama seperti yang terjadi pada tahun kejadian El Niño, naik turunnya curah hujan di Ambon sangat dipengaruhi oleh fenomena ENSO dibandingkan dengan Monsun maupun DM. Hal ini terlihat dari pengaruh ENSO hadir ketiga fasa La Niña yaitu tahun La Niña 2007/08, 2010/11, dan 2011/12, sementara Monsun hanya pada tahun 2010/11, dan DM hanya pada tahun 2011/12. Hal yang berbeda terjadi pada tahun Normal, dimana untuk tahun Normal 2005 memberikan hasil bahwa hanya Monsun yang berpengaruh terhadap naik turunnya curah hujan di Ambon, sedangkan hanya DM yang memberikan pengaruh terhadap naik turunnya curah hujan di Ambon pada periode Normal tahun 2013.

Berbeda dengan Ambon, hasil analisa korelasi parsial yang dilakukan memberikan hasil bahwa pada tahun kejadian El Niño yang dikaji, naik turunnya curah hujan di Tual dipengaruhi oleh fenomena ENSO, Monsun, maupun DM. ENSO dan Dipole Mode di tahun 2006/07, sedangkan Monsun di tahun 2006/07 dan 2009/2010. Pada tahun kejadian La Niña, naik turunnya curah hujan di Tual sangat dipengaruhi oleh fenomena ENSO pada periode La Niña 2007/08, sementara DM pada periode La Niña 2010/11. Hal yang berbeda terjadi 
pada tahun Normal, dimana Monsun berpengaruh terhadap naik turunnya curah hujan di Tual untuk tahun 2005 dan 2013, sedangkan DM memberikan pengaruh hanya pada tahun 2013.

Untuk Saumlaki, hasil analisa korelasi parsial yang dilakukan memberikan hasil bahwa pada tahun kejadian El Niño yang dikaji, naik turunnya curah hujan di Saumlaki dipengaruhi oleh fenomena Monsun dan DM di tahun 2006/07, sedangkan Monsun di tahun 2009/2010. Pada tahun kejadian La Niña, naik turunnya curah hujan di Saumlaki hanya dipengaruhi oleh fenomena DM yaitu pada periode La Niña 2007/08. Hal yang berbeda terjadi pada tahun Normal, dimana ENSO dan DM berpengaruh terhadap naik turunnya curah hujan di Saumlaki untuk tahun 2005 dengan pengaruh DM lebih besar dibandingkan dengan ENSO.

Dari hasil analisis korelasi berganda yang telah dilakukan, diperoleh hasil bahwa terdapat hubungan yang signifikan antara curah hujan di wilayah Maluku dengan ENSO, Monsun dan DM untuk semua kejadian ENSO yang dikaji. Hal ini dibuktikan dengan nilai koefisien korelasi berganda (koefisien penentu berganda) yang berkisar antara 0,748 - 0,999 (55,9 - 99,8\%) pada fasa El Niño, 0,674 - 0,964 (45,4 - 92,4\%) pada fasa La Niña dan 0,807 - 0,905 (64,6 - 81,9\%) pada fasa ENSO Normal. Hasil ini mengindikasikan bahwa naik turunnya curah hujan di wilayah Maluku sangat dipengaruhi oleh interaksi antara ENSO, Monsun dan DM dengan nilai koefisien korelasi berganda (koefisien penentu berganda) rerata terbesar terjadi pada fasa El Niño sekitar 0,916 (83,9\%), diikuti oleh pada fasa La Niña sekitar 0,838 (70,2\%) dan terakhir pada fasa ENSO Normal sebesar 0,862 (74,3\%). Dari hasil analisa di atas, dapat diindikasikan bahwa masih ada faktor-faktor lain selain ketiga faktor diatas yang mempengaruhi variabilitas curah hujan di wilayah Maluku, hal ini didasarkan dari nilai koefisien penentu berganda yang belum mencapai $100 \%$.

Ada atau tidaknya hubungan signifikan antara variabel yang dikorelasikan jangan diartikan sebagai tidak adanya hubungan antara variabel-variabel tersebut, tetapi dapat diartikan sebagai "tidak adanya korelasi” pada suatu hubungan yang linier. Hal ini disebabkan karena dalam analisa korelasi multivariabel yang dilakukan yaitu perhitungan koefisien korelasi, baik itu koefisien korelasi silang, koefisien korelasi ganda, maupun koefisien korelasi parsial, seluruhnya dilakukan dengan menganggap bahwa hubungan yang terjadi antar variabel adalah hubungan yang linier.

\section{Kesimpulan}

1. Variabilitas curah hujan di wilayah Maluku (Ambon, Tual dan Saumlaki) adalah berbeda satu dengan yang lain dan dipengaruhi oleh interaksi antara ENSO, monsun dan Dipole Mode. Pola curah hujan untuk Ambon adalah pola hujan Lokal, sedangkan pola curah hujan untuk Tual dan Saumlaki adalah pola hujan Monsun.

2. Variabilitas curah hujan di wilayah Maluku (Ambon, Tual dan Saumlaki) dipengaruhi secara bersama- sama (simultan) oleh ENSO, monsun dan Dipole Mode yang direpresentasikan dengan adanya perolehan nilai koefisien korelasi berganda untuk semua fasa ENSO yang diamati baik untuk fasa El Niño, fasa La Niña, serta fasa ENSO Normal yang sangat bervariasi untuk ketiga daerah dalam wilayah Maluku. Nilai koefisien korelasi berganda dan koefisien penentu berganda untuk Ambon adalah 0,748 dan 55,9\% pada fasa El Niño, 0,807 - 0,825 dan 64,6 68,06\% pada fasa ENSO Normal, serta 0,839 - 0,964 dan 70,3 - 92,92\% pada fasa La Niña. Nilai koefisien korelasi berganda dan koefisien penentu berganda untuk Tual berkisar antara 0,954 - 0,998 dan 91,0 - 91,96\% pada fasa El Niño, 0,881 - 0,905 dan 77,6 - 81,9\% pada fasa ENSO Normal, serta 0,674 - 0,857 dan 45,4 - 73,4\% pada fasa La Niña. Nilai koefisien korelasi berganda dan koefisien penentu berganda untuk Saumlaki berkisar antara 0,879 - 0,999 dan 77,2 - 99,8\% pada fasa El Niño, 0,892 dan 79,5\% pada fasa ENSO Normal, serta 0,801 dan 64,1\% pada fasa La Niña.

3. Variabilitas curah hujan di Ambon sangat dipengaruhi oleh fenomena ENSO dibandingkan dengan Monsun maupun DM untuk fasa El Niño dan La Niña, sedangkan Monsun dan DM lebih dominan pada ENSO Normal. Curah hujan Tual sangat dipengaruhi oleh ketiga variabel (ENSO, Monsun, dan DM) untuk untuk fasa El Niño dan La Niña, sedangkan Monsun lebih dominan dibandingkan dengan DM saat ENSO Normal. Sementara curah hujan Saumlaki lebih dipengaruhi oleh DM yang pengaruhnya hampir pada ketiga fasa ENSO, dibandingkan dengan pengaruh ENSO dan Monsun. 


\section{Daftar Pustaka}

[1] F. Iskandar., Variabilitas Curah Hujan Dan Debit Sungai Di Dak Brantas. Skripsi. Fakultas Matematika dan Ilmu Pengetahuan Alam Departemen Geografi Depok Januari 2012.

[2] B. H. K. Tjasyono., A. Lubis., Ruminta, dan S. W. B. Harijono., Dampak Variasi Temparatur Samudera Pasifik dan Hindia Ekuatorial Terhadap Curah Hujan Di Indonesia, Jurnal Sains Dirgantara, hal : 83-95, 2008.

[3] I. Hasan., Analisis Data Penelitian Dengan Statitik, PT Bumi Aksara, Jakarta , 2004.

[4] B. H. K. Tjasyono., Klimatologi Umum, Institut Teknologi Bandung, Bandung, 1999.

[5] K. E. Trenberth., The definition of El Niño. Bull Amer Meteor Soc 78:2771-2777, 1997.

[6] N. H. Saji, B. N. Goswami, P. N. Vinayachandran, and T. Yamagata., A dipole mode in the Tropical Indian Ocean, Nature, vol. 401, pag : 360-363, 1999. 
